\title{
KENANGA: WOMEN'S CULTURE (AN ANALYSIS OF NOVEL, A WORK OF FEMALE AUTHOR WITH PRESPECTIVE ELAINE SHOWALTER CULTURE MODEL)
}

\author{
Yessy Hermawati \\ Program Studi Pendidikan Bahasa dan Sastra Indonesia \\ FKIP-UNINUS \\ Corresponding author: yessy.hermawati@gmail.com
}

\begin{abstract}
In understanding the women's culture, historians see and distinguish various aspects of identity, roles, relationships, attitudes and pictures of women's lives formed in the culture of society in general. Female writers also express and present the women's culture in their works. This study discusses how the women's culture is represented in a novel written by a woman. A work that is written with attention to the cultural elements of women that presents women's lives through experience and narration. The object analyzed in this study is Oka Rusmini's novel entitled "Kenanga" which tells the women's lives with Balinese cultural background. Oka Rusmini, the author is also a Balinese woman. The novel is analyzed by using the approach of Subjectivity (Spivak,1994) and Elaine Showalter cultural model (Showalter,1982) especially women's writing and women's culture model. This study shows that women authors represent experiences and women's issues in their works. Women authors also write down their responses and perspectives on the patriarchal culture that surrounds their lives with a Balinese cultural setting. Oka Rusmini also conveys resistance of social and cultural constructions which make women become subordinate through the attitude and life of the characters in her novel.
\end{abstract}

Keywords: women's culture, female author, Kenanga, Oka Rusmini

\section{Introduction}

Women's life experience is always interesting to narrate that present in various writing form one of them is literature. Women's literary works are represented in various stories and perspectives. Literary works can also contain women's voices that live in patriarchic traditions or those who are aware of the inequalities of sociocultural structures. In this case a woman either real or fictional must find a way to articulate themselves and invite people to listen to the articulation in order to reconstruct or deconstruct the various stereotypes that the community puts on women. This is part of the women's culture.

Sholwater (1982) argues that women's culture is about the values and women's way of life as part of a living community and doing activities together. Women's culture is 
also about the role, relations and forms of women's communication in society. Gerda Lerna (1978) also reveals that discussing women's activities and issues based on women's perspectives is the women's culture. Here, women writers act as creator. The author can create the world and culture as a place of resistance is presented, where stereotypes are questioned and where cultural myths are deconstructed. So that women's culture can be seen through narration written or produced by female writers in their works.

Indonesian novels or short stories written by female writers have presented many cultural narratives of women, including works written by Hamidah, Suwarsih Djojopuspito, N.H. Dini, Ayu Utami, Oka Rusmini, and other female writers. This paper focuses on one novel by Oka Rusmini, which narrates the life of Balinese women in dealing with various domestic, public, social and cultural issues. Oka Rusmini herself is a Balinese woman who is very close to the context and setting that she tells in her novel. This novel becomes interesting to be studied because Oka Rusmini as a Balinese woman reveals Balinese cultural construction that is oftentimes disadvantage women. Here, she voiced her resistance and thoughts about Balinese women.

\section{Literature Review}

Literary work is not a reality, but literary works can reflect reality. This also occurs in the novel as part of the literary genre. As stated by Teeuw (1984) that there is a tension relationship between reality and fiction in novels. In a novel, a real and fictional world are interlocking to one another, one means nothing without the other. The existence of literary works is side by side with reality world, what happens in reality oftentimes inspires the author to represent in the literary works they create. The authors finally have the space to create their own world, and the various realities that suit their imagination.

Literary works also cannot be separated from the concept of subjectivity, which according to Spivak (1994) there are three concepts that always work and shifted in the humanities discourse i.e. language, world and consciousness. The world of reality and fiction is built and operated with language manifested in the form of text. In literary works, especially those written by women, the concept of female subjectivity is not only in the act of language that reflects reality. But more than that there is a relationship between subject, language and world written through an interpretation.

The literary work in its own way provides space for the language to deliver ideas about the dynamics of society, anxiety, resistance and even support for women's lives. Oka Rusmini uses language to tell stories and conveys her interpretation concerning the socio-cultural life of Balinese women through her novels. She presents Balinese women's experiences and voices. Pradopo (2000) suggests that women may be able to communicate women's experiences better, especially things that men cannot know or experience. However, women's experience is certainly not the same, it also depends on the background of race, social class, religion, group and ethnicity. So that women's voices are not singular or similar, but it can be diversely articulated. 
In Feminist Criticism in the Wilderness, Showalter (1982) reveals that gynocritics theories that examine the history of women literature (women as writers), writing styles, themes, genres, creativities, and women writers' professions as an association, development and culture of women writers. This gynocritics theory presents four models to study the writings of women writers. The four models are women's writings and women's body, women's writings and women's language, women's writings and women's psyche, Women's writings and women's culture. This article focuses on women's writings and women's culture, according to Showalter(1987) this model is a more complete and comprehensive model in understanding about the narration of women's culture written by female writers. Because the cultural point of view combines ideas about the body, language, and psychology that are based on the social and cultural context contained in the life of women. In other words, socio-cultural aspects play an important role in constructing the identity, roles and relationships of women's lives.

In the explanation of women's writings and culture models, Showalter (1982) reveals that a major advantage in this model is "it show how the female tradition can be positive source of powerless-ness; its can generate its own experiences and symbols which are not the observe of the male tradition ". This showalter's point of view emphasizes the importance of recognizing and understanding the elements embodied in women's culture to better understand the life and issues faced by women themselves. With the model of Women's writings and women's culture, hence novels that narrate the women's lives and experiences by women writers can show that the writings of women writers can become a source for women's life force and the exposure of women's experiences. By considering these two aspects in the works of women writers, will facilitate us to understand the values in literary works, especially novels. In addition, the readers of literary works (novels) will also be easier to recognize and understand the world of women from women's point of view who convey their life experiences through texts.

\section{Research Method}

This paper discusses one of Oka Rusmini's novels entitled Kenanga which was republished in 2017. The main reason for choosing this novel as the research object is first, because the author is a woman. Second, she is consistent enough in writing about women's experiences especially Balinese Women in their social cultural context and is open to various good and bad circumstances experienced by women. Third, I see Oka Rusmini as a reflection of a woman with broad and experienced insight, she as a writer who represents women in articulating themselves through literary works.

This study aims to see how women's culture is represented in literary works written by women (Oka Rusmini). The assumption is women's culture represented in Kenanga novel contains Oka Rusmini's opposition to patriarchal culture which is affirmed in Balinese custom and culture. It is also a picture of woman's attempt to no longer be an object, but to emphasize her identity as a self or subject that has control over her. 
The research method used is content analysis using Showalter women's writing's model and women's culture to gain a picture of women's culture presented by the author in the novel. This study gets through three stages those are data collection, data analysis and data presentation. The novel is also analyzed by looking at narrative techniques and observing the perspective, the background and the character to interpret the women's culture presented through the elements of the Showalter model in the context of socio-culture and also the subjectivity of the woman herself.

\section{Discussion}

To be able to see the representation of reality in literary works, it is necessary to understand the narrative structure formed by the work. Particularly, the narrative structure to be analyzed in Kenanga novel is the point of view, plot, character, and background that is integrated with the third person's point of view. The author uses the third-person perspective (omniscient) by building the main characters in this novel that is Kenanga, Kencana, and Intan. The author also acts as a narrator who tells anything about these main characters. The narrator knows everything and creates all the experience in the characters. These three main characters become a tool for writers to articulate women as subjects that also describes the subjectivity of Oka Rusmini as a female writer. In this case, it can be seen that Oka Rusmini has an awareness of herself as a Balinese woman and her awareness produce text by presenting the main characters Kenanga, Kencana and Intan who recognize the world with three concepts put forward by Spivak (1994) namely awareness, language and world.

Another point of interest in this novel is the setting, the setting here does not only present the socio-cultural situation of the novel, but also the symbol of the position and the changes experienced by the characters. According to Pearce and Stacey (1999) that in the romance the female character experienced what he called "the hope of transformation that poses the possibility of change, progress and solution". Such a journey is an important element in seeing women in the novel analysis of women because it symbolizes a change from the old self into a new self. This frame supports the viewpoint chosen by the author who is also a narrator. Furthermore, by using Showalter Model women's writing's and women's culture, it can be seen that Kenanga novel written by Oka Rusmini presents elements as follow:

\section{Women's Strength and Sisterhood}

The aspect of women's strength and sisterhood is the idea and experience of united women in the form of self-affirmation and identity centered on women sisterhood that derived from the interpretation of women themselves. According to Humm (1989) the sisterhood is based on the awareness that all women regardless of class, race and ethnicity, share the same problem that is patriarchy. In this case, the problem faced by women is how to deal with community values that are still constructed by patriarchal power. This issue is often presented by female writers in their works. Oka Rusmini also presents the problem of how women are faced with customs and patriarchal values in Balinese society. Oka Rusmini's narrative in her 
novel is a form of Oka Rusmini's awareness of Balinese women's experience to be a source of strength and understanding concerning female bonding.

In the novel Kenanga, Oka Rusmini presents the story and experience of the main women characters namely Kenanga, Kencana and Intan. The three characters experienced problems related to some of the same male characters. However, Oka Rusmini builds these female characters to strengthen and protect each other, seeking self-awareness together to rise and continue to conquer circumstances that sometimes-put women in weak positions. The relationship between women's characters can be seen as a form of female affiliation that according to Showalter (1987) are manifested in two forms i.e. in the context of women's relationship without blood tie and affection between younger sister and older sister or between mother and daughter who were built from the beginning while still in the womb and known as symbiotic process.

In this novel, the form of sisterhood depicted in the context of female affiliation in blood relations, elder sister and younger sister (Kenanga and Kencana), and Mother and daughter (Kenanga and Intan). Kenanga, the main character of the novel is the eldest daughter in her family. Kencana is Kenanga's younger sister and also the youngest daughter in the family. They are Balinese women, with Brahmana family backgrounds, the highest caste in Balinese culture. Born and live with the nobility they got from the bloodline, demanding that they also have to carry out their roles and relations with everyone according to the customs and ancestral cultures. There are many custom rules that set up their roles, attitudes and behaviors. Meanwhile, Intan is Kenanga's daughter who were born outside marriage bonds, which she should still carry a line of nobility from his mother. However, because her birth was concealed and raised by a family of sudra caste, Intan has to live a different life from her mother. She has to play the role of Sudra woman. Oka Rusmini illustrates that being a Brahmana and Sudra Woman in Balinese society still have consequences.

These three figures are presented by Oka Rusmini to illustrate that the relationship of sisterhood that they have because the blood ties are not directly a source of strength for them to face the problem of life as woman. However, Oka Rusmini voices the consciousness of sisterhood and being a woman that make the relationship as a power to be a woman. Just like Kenanga and Kencana in this novel is told to experience the conflict of love triangle. They both love the same man. But this situation is not a source for competition or a reason to hate each other, but to be aware of their existence as women, as children, as well as the family of the highest caste with a strong customary code. Different situations will be found when the story is written by male writers, as most male writers will describe the female rivalry in obtaining a place and the attention of a man. As expressed by Showalter (1987) the characters created by the male authors are somewhat idealized and melancholy projection or repressed male self. Male writer's projections based on men's interests and views in the women's writings are trying to be changed by suggesting women's views and experiences. 
Oka Rusmini builds the three main female characters in the novel with different characters. Kenanga is presented as an independent, upright, well educated Brahmana lady and is a lecturer at a university in Bali, in order to keep her family's name the highest caste family and protect her sister's happiness she cannot marry the man she loves and gave birth to a daughter Intan without getting married. By this, Kenanga must accept the consequences that it will be a topic of negative talk in the Griya neighborhood (the residence of the Brahmin caste). With the conflict faced by Kenanga Oka Rusmini displays Kenanga as a figure of woman who embraces her identity and her role not only because of her nobility but also because she is an educated woman, possessed of knowledge, strong principle, confidence and toughness because of awareness that she also must be able to survive for the sake of other women in her life cycle. Kencana, Kenanga's mother, and Intan with all the problems presented in Kenanga's life. For Kenanga, are the source of strength for her to have consciousness as woman and to become a woman.

The Character of Kencana, is presented by Oka Rusmini in this novel as Kenanga's younger sister who also holds the title of nobility of the Brahmin caste society. She is described as a beautiful, gentle and perfect woman as a normative woman. This is shown in the following novel quotation:

"sebagai perempuan Kencana memang sempurna. Kulitnya putih, mulu.

Di parasnya seperti terbayang seorang putri yang menunggu sang pahlawan datang menjemputnya pada suatu hari nanti. Paras yang begitu lembut, seolah mustahil mengenal dosa. Wujud sempurna keindahan, seakan-akan sang Hyang Jagat bukan bermaksud menciptakan manusia, melainkan sebuah mahakarya seni. Lelaki mana yang tak terpikat? Bahkan Kenangan pun mengaguminy."(Kenanga, 2017: 14)

Based on the above quote, it appears that Oka Rusmini presents a different character representation and female form of Kenanga. Kencana is presented as a normative woman, in which case the dominant feminine performance becomes a better thing in society against women.

The two female characters portrayed by Oka Rusmini in her novel continue to address the problems posed by their relations with Men, even with the same man. Kenanga and Kencana have relationship with Bhuana, a man figure with the identity as Brahmin caste descendant, well-educated, works as a doctor and a lecturer. Bhuana is the image of an ideal man in society. Kenanga has an emotional connection with Bhuana, from that relationship Kenanga has a child without marriage. This is because Kenanga has to let Bhuana marry her own sister Kencana. Kenanga must relinquish that for the sake of the family's request, both her family and Bhuana's family who long for the normative women, in this case, beautiful, come from families of the same caste, no need to go to school, serve and obey their husbands and families, and the main thing is able to prepare ceremonies and offerings for prayer and customary ceremonies. 
Proceedings of the $1^{\text {st }}$ Annual International Conference on Language and Literature, 18-19 April 2018, Fakultas Sastra, UISU, Medan, Indonesia.

Bhuana's presence creates problems and conflicts to Kencana and Kenanga. But in the end, Oka Rusmini in her novel describes the characters of these two different women having to find each other's strengths and help each other in bearing the wounds and burdens of their relationship with Bhuana, a male. This can be seen in one of the following quotation.

"Bhuana, Tiang tahu tiang tidak berhak mencampuri urusanmu dengan

Kencana. Tapi, hanya Tiang yang kencana percaya dan dia minta tolong tiang membantunya" (Kenanga, 2017: 36).

However different characters and identities Kenanaga and kencana have, it does not constrain the realization of female bonding between the two. Women's strength and sisterhood do not only about understand each other with themselves and their hearts, but they are also able to sacrifice each other, help and reinforce each other. Oka Rusmini also features Kenanga character to remind that women should also be able to free themselves from men's view of women's ability and dependence socially, economically, psychologically and desire to love and to be loved in marriage on men.

Another form of women's strength and sisterhood in the context of blood tied relationship is the relationship between mother and daughter. In Novel Kenanga, Oka Rusmini presents this form of relationship through Kenanga and Intan characters. Intan is Kenanga's daughter who was born without marriage. They were separated when Intan was born because it would be a disgrace for Kenanga and also her family who come from Brahmin caste. After several years Intan is reunited with Kenanga in the Griya family. The presence of Intan gives strength to Kenanga, it is like she rediscovers the light of her life. This is a picture of the unbearable bond between mother and daughter, this is shown in the quotation as follows.

"Kehadiran Intan telah menuntunnya kepada suatu kekuatan yang mengikat mereka berdua. sorot mata anak itu penuh tantangan, begitu hidup, amat memikat dan menimbulkan gairah aneh pada dirinya. Kenanga tidak sangup membayangkan hidup tanpa Intan." (Kenanga,2017: 4).

Intan is present as a servant of an unknown Sudra caste origin. Where in the Griya family (Brahmin) a person who comes from a lower caste should not be treated the same. However, the mother and daughter bonds make Kenanga protects, educates and strives for Intan to be treated as Brahmin family without dismantling the origins. This can be shown in the following quotation.

"Tiang menyayangi anak itu. mencintainya. Padanya tiang menemukan masa kanak-kanak tiang. Obsesi tiang. Tiang tidak minta banyak. Tiang hanya ingin semua orang di rumah ini menghargai dia. sebagai layaknya manusia." (Kenanga, 2017: 87).

Meanwhile, Kenanga is also a source of strength for Intan. She finds the figure of her mother, friend and mentor of her life who teaches her many things about life.

"..Dia banyak mengajari sesuatu yang tidak tiang ketahui. Tentang hidup dan tentang Tanggung jawab." (Kenanga 2017: 239). 
Proceedings of the $1^{\text {st }}$ Annual International Conference on Language and Literature, 18-19 April 2018, Fakultas Sastra, UISU, Medan, Indonesia.

Oka rusmini also describes the tough Intan in getting through the suffering and obstacle of life, this is not escaped from Kenanga's guidance. As one of the characters in the novel say about Intan,

"...Intan alangkah bahagianya kau? seorang perempuantegar terus menusukan keberaniannya untuk memberikan dirimu kepribadian." (Kenanga,2017: 242).

The relationship of mother and daughter Kenanga novel portrays the power of women who come from the love of their anatras. They learn from the life experiences they have been through. This form of relationship is an important feature in the work of female authors. As revealed by Wolf (1957) that we think back thruogh our mothers if we are women. In addition, the relationship between Kenanga and Intan in this novel becomes the main motivation in shaping themselves as woman who can have position in society.

The forms of relationship between the three characters i.e. Kenanga, Kencana and Intan that are related produce women's strength, awareness and sisterhood. This is in accordance with Showalter's culture model (1987) which reveals that the work of female writers will produce a sisterhood of share passion and suffering, women who are sobbed and struggled and rebelled.

\section{Explaining women's experiences}

The women's experiences that are articulated can become knowledge and awareness for other women. As expressed by Showalter's culture model (1987) that women's experience is an important aspect that can be seen in women's culture, which presents in the work of female authors. This is reinforced by Lerner's opinion (1979) which reveals that in order to understand the women's culture, it is important to see the women's experience from the point of view of women themselves.

In novel Kenanga, Oka Rusmini describes women's experiences related to the role and position of women in Balinese society. It can be seen from the experience of three main characters in this novel are Kenanga, Kencana and Intan. The position of women in Balinese society is still seen from the Family caste. The women from Brahmin caste have a high position and must be respected and served and can only marry Men of the same caste. If they marry a man who has a lower caste than their family it will be considered as customary offense, and the woman is expelled from her griene and family. While men of Brahmin caste can marry women who come from any caste. From here it can be seen that Balinese culture still provides wider space for men.

Meanwhile, women who come from the caste of Sudra should serve and honor the Griya family (Brahmin caste). Daughters of Sudra caste should be the servants of Brahmin family. This happens to Intan when she returns into her mother's family, as illustrated in the following quotation:

"Adat di lingkungan griya lazimnya memang demikian. Anak-anak orang biasa yang rajin bekerja tetapi miskin dan tak mampu sekolah, 
Proceedings of the $1^{\text {st }}$ Annual International Conference on Language and Literature, 18-19 April 2018, Fakultas Sastra, UISU, Medan, Indonesia.

sering diserahkan orang tuanya untuk jadi pembantu di griya. Sekaligus sebagai tanda persembahan dan bukti kesetiaan pada kaum bangsawan. Ada kepercayaan bahwa dengan mengabdi pada griya, mereka akan senantiasa dilimpahi kebahagian. Murahrezeki dan dilindungi para leluhur.", (Kenanga, 2017: 5).

From the description Oka Rusmini illustrates that in Balinese society, the origin of the family has determined the position of women in society. The freedom given to Brahmin men to have wives of any class of caste makes women compete for positions as wives in the Brahmin caste. So for women from a low caste can get into a high caste. Patriarchic cultures give more space to Men.

Oka Rusmini also illustrates that the position of women in Balinese society is not only from the origin of the family, but also from the learning and education process. It is depicted in Kenanga and Intan figures. Kenanga upholds her education until she becomes a Lecturer at one of the universities in Bali. Oka Rusmini builds a brilliant, tough and successful Kenanga identity to counter that a woman is not only respected because she is noble, good at making offerings, diligently preparing for ceremony only. But the main thing is that she is able to deal with life itself and understand herself with the knowledge she has. This picture is seen from the following quotation:

"...dia harus belajar, belajar, dan belajar. Tak seorang pun boleh menyentuhnya bila dia sedang husuk mereguk ilmu pengetahuan, sebab hanya pada ilmu pengetahuan seluruh impian dan harapannya tertumpahkan. Dengan menguasai ilmu pengetahuan dia merasa aman. Setidaknya dia merasa punya modal untuk dihormati dan dihargai orang karena isi kepalanya bukan karena kebetulan dia dilahirkan sebagai perempuan brahmana yang kaya raya" (Kenanga, 2017: 123)

The experience of educated women as a process of becoming women is also illustrated by Intan. The real Intan is the descendant of Brahmin caste, but because of her concealed births she must live a life as a Sudra woman. But, Kenanga as her biological mother still emphasizes to Intan, that the position of women is not only from the origin of the family, but also determined by her knowledge and education. Like the one that Kenanga always emphasizes to Intan "Kau benar, nak. Kau memang harus rajin belajar, Serajin-rajinya. Kau harus berusaha menjadikan dirimu berharga." (Kenanga: 2017: 111). Oka Rusmini has voiced that in Balinese society the position is greatly determined by their family class in custom. But she also voiced another experience through Kenanga and Intan figures that the position can still be shaken and strengthened by the level of women's education. This implies that learning is one way to become a woman.

In addition, there is also a questionable female role in Balinese society. The role of woman that is yearned when the woman becomes a wife. In the novel Kenanga this problem is also illustrated through the character of Kencana. Her life is considered perfect, because Kencana married a man who came from the same caste with her 
family, then she become a submissive and beautiful wife who serves her husband. Even though, her household life is not as beautiful as people imagine, because her husband Bhuana has never loved her. The marriage and customary rules that force them to meet the normative culture and custom. Through the experience of Kencana's role, Oka Rusmini conveys that in Balinese society, no matter how bitter and bad the marriage is, as long as she has received and retained her role as a Wife, is still seen as a good woman.

Meanwhile, women who come from any caste, if they are not married and do not have roles as a wife will show a negative stereotype on them. Oka Rusmini represents this issue to Kenanga figure who choose not to marry. Kenanga has a wellestablished, educated and self-employed job. The negative stereotype comes from family and society. People at Griya or Her Family often compare Kenanga with Kencana and labeling her as a frustrated woman. This is reflected from the following quotation:

"Sial sekali nasib Kenanga. Dia tak bisa menerima perkawinan Kencana. Sudah dilangkahi, eh, suami Kencanaorangnya ganteng dan gagah sekali. dokter lagi. Jelas sekali hatinya sakit .... Istilahnya Frustasi, begitu, kasihan Sekali" (Kenanga, 2017: 56).

It's not only her family that label the role of Kenanga as a woman who chooses not to marry. Her mother also assumes that Kenanga has got the curse. This is illustrated in the following quote: "Tadinya ibumu mau bertanya pada balian. Siapatahu Kenanga kurang sesaji, atau mungkin ada orang jahat yang menganggu dia dengan gunaguna.." (Kenanga, 2017: 91). Through Kenanga's experience, Oka Rusmini voices that in Balinese society the role of Wife remains a hallmark of women's honor. Although women are still harmed because of the miserable marriage, violence and double burden. While women who are independent and can stand upright in their lives, if they are not married it will still fall on the negative labeling. How Patriarchy power is still difficult to conquer in determining the position and role of women in the background of Balinese Culture that represent in Novel Kenanga.

\section{Conclussion}

Based on the discussion of novel Kenanga by oka rusmini, it can be seen that female writers who have the same cultural background with the story characters will present an understanding of the elements of the women's culture in the Writing. The cultural elements of women depicted in Kenanga novel are about women's strength and sisterhood and the presentation of women's experiences in Balinese cultural life. This is done to recognize the women's culture featured by female writer. The picture is gained in accordance with the opinion of Showalter cultural model which confirms that by examining women's culture in women's writings will give an understanding of the representation of the woman's own life.

Novel Kenanga worked by Balinese Female writer Oka Rusmini gives an idea of the life of Balinese women who are very strong with the rules of custom and culture. The form of female culture is depicted in the form of the source of women's strength and 
Proceedings of the $1^{\text {st }}$ Annual International Conference on Language and Literature, 18-19 April 2018, Fakultas Sastra, UISU, Medan, Indonesia.

sisterhood in the form of female bonding. And the exposure of Balinese women's experiences, especially in obtaining their position and role, is still strongly influenced by patriarchal culture. But Oka rusmini with the representation of her characters tries to voice the resistance by using the characters and figures' experiences to open space about the awareness of women to gain a better position and role. Also, to get the goal of the Showalter's cultural model (1982) at the same time "to get away from the masculine systems, hirarchies, and values and to get the primary and self-defined nature of female culture experience."

\section{References}

A, Teeuw. (1984). Sastra dan Ilmu Sastra: Pengantar Teori Sastra. Jakarta: Dunia Pustaka Jaya

Humm, Maggie. (1989).The Dictionary of Feminist Theory. New York: Harvesther WheatSheaf

Lerner, Gerda. (1978). The Majority Finds its Place: Placing Women in History. Oxford: Oxford University Press

Pearce, Lynne and Jackie Stacey, eds. (1999). Romance Revisited. New York: New York University Press

Pradopo, Rachmat Djoko. (2000). Kata Pengantar dalam Toeti Heraty, Wanita dimata Wanita: Prespektif Sajak-Sajak Toeti Heraty. Bandung: Nuansa

Rusmini, Oka. (2017). Kenanga. Jakarta: Grasindo

Showalter, Elaine. (1982). "Feminist Criticism in the Wilderness". In the Elizabeth Adel (ed.), Writing and Sexual Difference. Chicago: University of Chicago Press

Showalter, Elaine. (1987)."Toward a feminist Poetics". in Rick Rylance(ed.). Debating Texts: A Reader in Twentieth-Century Literary Theory and Methode.Milton Keynes: Open University Press

Spivak, Gayatri Chakravorty. (1994). "Feminism and Critical Theory" in Robert Con Davis and Ronald Scleifer. Contemporary Literary Criticism-Literary and Cultural Studies. New York: Longman Publishing Group

Wolf, Virginia. (1957). A room of One's Own. New York: Harcourt Brace Javanovich 